\title{
ANALISIS KEMAMPUAN BERPIKIR KREATIF MATEMATIS MAHASISWA PGSD PADA MATERI BANGUN RUANG DI STKIP MELAWI
}

\author{
Yumi Sarassanti ${ }^{1}$ dan Mutazam ${ }^{2}$ \\ ${ }^{1,2}$ Dosen STKIP Melawi \\ Jln. RSUD Melawi Km. 04 Kecamatan Nanga Pinoh Kabupaten Melawi \\ yumisarassanti@yahoo.co.id, nursammutazam@gmail.com
}

\begin{abstract}
The purpose of this study was to analyze the mathematical creative thinking abilities of PGSD students on thespace building material in STKIP Melawi. The method of this research was descriptive method in the form of observation. The subject of this research was PGSD students. The results showed that $48,5 \%$ of students answered the questionsaccording to the Fluency indicator and they were categorized as low, $45 \%$ of the students answered the questionsaccordingto the Flexibility indicator and they were categorized low, $44,5 \%$ of the students answered the questions accordingto the Originality indicator and they were categorized as low, and 46,5\% of the students answered the questions according to the Elaboration indicator and they categorized as low.
\end{abstract}

Keywords: Mathematical Creative Thinking, Space Building

\begin{abstract}
Abstrak: Tujuan penelitian ini adalah menganalisis kemampuan berpikir kreatif matematismahasiswa pendidikan matematika pada materi bangun ruang di STKIP Melawi. Metode yang digunakan dalam penelitian ini adalah metode deskriptif dengan bentuk penelitian survei. Subyek dalam penilitian ini adalah mahasiswa pendidikan matematika. Hasil penelitian menunjukkan bahwa 48,5\% mahasiswa menjawab soal yang sesuai dengan indikator Fluency dan dikategorikan rendah, $45 \%$ mahasiswa menjawab soal yang sesuai dengan indikator Flexibility dan dikategorikan rendah, 44,5\% mahasiswa menjawab soal yang sesuai dengan indikator Originalitydan dikategorikan rendah, dan $46,5 \%$ mahasiswa menjawab soal yang sesuai dengan indikatorElaborationdan dikategorikan rendah.
\end{abstract}

Kata Kunci : Berpikir Kreatif Matematis, Bangun Ruang

$\mathrm{M}$

atematika merupakan salah satu pelajaran yang sangat penting dalam pengembangan potensi diri di sekolah. Oleh sebab itu pelajaran matematika yang diajarkan di sekolah adalah pelajaran matematika yang dapat menata nalar, membentuk kepribadian, menanamkan nilai-nilai, memecahkan masalah dan melakukan tugas tertentu.
Fakta di lapangan yang dilakukan oleh Sari dkk (2015) mengatakan bahwa rendahnya kemampuan berpikir kreatif matematis mahasiswa di Indonesia oleh beberapa faktor. Salah satunya yaitu mahasiswa tidak terbiasa menyelesaikan masalah dengan beberapa alternatif lain. Selain itu, rendahnya kemampuan berpikir kreatif matematis mahasiswa juga 
disebabkan karena mahasiswa tidak terlibat secara aktif dalam kegiatan pembelajaran. Penyebab rendahnya kemampuan berpikir kreatif matematis mahasiswa terjadi karena umumnya guru sibuk sendiri menjelaskan materi yang telah disiapkan, sedangkan mahasiswa hanya menjadi penerima informasi yang baik. Akibatnya mahasiswa hanya mencontoh apa yang dikerjakan guru tanpa mengetahui makna dari solusi masalah yang dijelaskan. Hal itu menyebabkan mahasiswa beranggapan bahwa soal tersebut hanya bisa dikerjakan seperti apa yang di contohkan sebelumnya[1].

Berdasarkan pemaparan di atas, kemampuan berpikir kreatif matematis merupakan salah satu kemampuan yang harus dimiliki oleh setiap mahasiswa. Namun, beberapa hasil penelitian menunjukkan bahwa kemampuan berpikir kreatif mahasiswa masih mencapai hasil yang kurang sesuai dengan yang diharapkan. Penelitian Hendrayan (2008) mengungkapkan bahwa kemampuan berpikir kreatif matematis hanya terdapat mahasiswa yang berkemampuan tinggi dan sedang saja, tetapi tidak terjadi dengan mahasiswa yang berkemampuan rendah. Sehingga tidak semua mahasiswa dalam penelitian ini mengalami peningkatan $\begin{array}{lcr}\text { kemampuan } & \text { berpikir } & \text { kreatif } \\ \text { matematisnya[2]. } & \text { Uraian di atas }\end{array}$ memotivasi peneliti untuk menganalisis kemampuan berpikir kreatif mahasiswa pada materi bangun ruang di STKIP Melawi.

Adapun masalah penelitian ini adalah "Bagaimana kemampuan berpikir kreatif matematis mahasiswa pada materi bangun ruang di STKIP Melawi?". Tujuan dari penelitian ini adalah untuk mengetahui kemampuan berpikir kreatif matematis mahamahasiswa pada materi bangun ruang di STKIP Melawi.

Uraian di atas memotivasi penulis untuk mengkaji lebih lanjut mengenai kemampuan berpikir kreatif matematis mahasiswa pada materi bangun ruang di STKIP Melawi. Kemampuan berpikir kreatif secara umum dipahami sebagai kreativitas. Seringkali individu yang dianggap kreatif adalah pemikir sintesis yang benar-benar baik yang membangun koneksi antara berbagai hal yang tidak disadari orang-orang lain secara spontan. Kemampuan berpikir kreatif matematis merupakan salah satu kemampuan yang harus dimiliki oleh setiap mahamahasiswa karena apabila mahasiswa menemukan masalah maka mahasiswa akan menggunakan kemampuan berpikir kreatifnya saat menyelesaikan masalah tersebut.

Kemampuan berpikir kreatif adalah suatu kegiatan mental yang digunakan seseorang untuk menyusun ide atau gagasan baru untuk menyelesaikan 
pemasalahan yang muncul dalam matematika dan menemukan banyaknya kemungkinan jawaban terhadap suatu masalah yang didasari informasi yang didapat atau tersedia. Kreativitas tidak hanya berhubungan dengan bidang seni saja tetapi juga ada kreativitas dalam pembelajaran matematika. Menurut Yulistiyarini (2015) kreativitas dapat berupa hasil berpikir kreatif dalam menyelesaikan suatu masalah dalam menghasilkan suatu produk. Kemampuan berpikir kreatif bagi siswa bukan hanya bermanfaat bagi pemecahan masalah tetapi memberikan kepuasan individu karena merasa apa yang dipelajari dapat bermanfaat bagi kehidupannya[3].

Sedangkan menurut Rosanti (2015) berpikir kreatif merupakan sebuah kebiasaan dari pikiran yang dilatih dengan memperhatikan instuisi, menghidupkan imajinasi, mengungkapkan kemungkinankemungkinan baru, membuka sudut pandang yang menakjubkan, dan membangkitkan ide-ide yang tak terduga[4]. Menurut Husen (2014) mengatakan bahwa berpikir kreatif dapat diartikan sebagai berpikir secara logis dan divergen untuk menghasilkan ide atau gagasan yang baru. Produk dari berpikir kreatif itu sendiri adalah kreativitas[5].

Berpikir kreatif memuat aspek keterampilan kognitif, afektif, dan metakognitif. Keterampilan kognitif tersebut antara lain kemampuan mengidentifikasikan masalah dan peluang, menyusun pertanyaan yang baik dan berbeda, mengidentifikasikan data yang relevan dan yang tidak relevan, masalah dan peluang produktif menghasilkan banyak ide (fluency), ide yang berbeda (flexibility), dan produk atau idea yang baru (originality), memeriksa dan menilai hubungan antara pilihan dan alternatif, mengubah pola pikir dan kebiasaan lama, menyusun hubungan baru, memperluas, dam memperbaharui rencana atau ide (Sumarmo, 2010)[6].

Berdasarkan uraian di atas dari beberapa pendapat para ahli tentang pengertian berpikir kreatif pada umumnya sama tapi dari sudut pandang pendefinisiannya yang berbeda maka dapat di simpulkan bahwa berpikir kreatif adalah kemampuan untuk menghasilkan ide-ide dalam menyelesaikan masalah yang muncul dalam matematika. Adapun indikator kemampuan berpikir kreatif yang digunakan dalam penelitian ini adalah 
Tabel 1. Indikator Kemampuan Berpikir Kreatif Matematis

\begin{tabular}{llr}
\hline Indikator & \multicolumn{3}{c}{ Keterangan } \\
\hline Berpikir & Mengemukakan beragam & jawaban \\
Kreatif & dalam menyelesaikan & masalah \\
& matematis (Fluency) & \\
& Menemukan beragam cara dalam \\
& menyelesaikan masalah matematis \\
& (Flexibility) & \\
& Menghasilkan pemikiran sendiri \\
& dalam menyelesaikan masalah \\
& matematis (Originality) \\
& Menambah atau memperinci detail- \\
& detail dari suatu gagasan matematis \\
& (Elaboration) \\
\hline
\end{tabular}

Bangun ruang merupakan bangun matematika (matematica) yang memiliki isi atau volume. Bangun ruang dalam matematika dibagi menjadi beberapa bangun ruang yakni sisi, rusuk dan titik sudut.

Macam-macam bangun ruang yang digunakan dalam penelitian ini adalah:

1. Kubus adalah bangun ruang yang dibatasi oleh enam bidang sisi yang kongruen berbentuk persegi yang bentuk dan ukurannya sama. Bidangbidang tersebut merupakan sisi alas dan sisi tegak.

2. Balok adalah suatu bangun ruang yang dibatasi oleh enam (bidang) sisi atau 3 pasang sisi yang kongruen berbentuk persegi panjang. Bidang-bidang tersebut merupakan sisi yang berbentuk persegi panjang

3. Prisma adalah bangun ruang yang dibatasi oleh bidang sejajar yang sama bentuk dan ukurannya. Bidang-bidang tersebut merupakan sisi alas dan tutup prisma. Bidang-bidang yang lain berpotongan menurut rusuk-rusuk yang sejajar. Luas permukaan prisma atau yang biasa disebut luas selimut prisma dapat dihitung dengan menghitung semua sisi-sisi prisma tersebut. Dalam pembahasan ini, yang akan dibahas adalah prisma segi tiga.

4. Limas adalah bangun sisi datar yang selimutnya terdiri atas bangun datar segitiga dengan satu titik persatuan. Titik persatuan itu disebut titik puncak limas. Bidang-bidang pembentuk limas disebut bidang limas dan garis yang merupakan perptongan antara dua sisi limas disebut rusuk limas. Pada limas pasti ditemukan satu titik puncak, satu sisi (bidang) alas dan tiga atau lebih segitiga yang merupakan selimut limas. Jarak antara titik puncak limas dengan 
bidang alas disebut tinggi limas. Serupa dengan penamaan prisma, nama limas juga ditentukan dari nama alasnya. Dalam pembahasan ini, yang akan dibahas adalah limas segi empat.

\section{METODELOGI PENELITIAN}

Bentuk penelitian ini adalah penelitian kualitatif deskriptif. Menurut Nasir (1988:65) penelitian deskriptif dapat dibagi dalam beberapa bentuk yaitu peneltian survei, studi kasus, analisis pekerjaan dan aktivitas, tindakan, penelitian perpustakaan dan dokumenter. Bentuk penelitian yang akan digunakan dalam penelitian ini adalah penelitian survei[7]. Survei yang dimaksud adalah kasus di STKIP Melawi dimana peneliti melakukan analisis pekerjaan mahasiswa yang berkaitan dengan bangun ruang.

Populasi Subjek dalam penelitian ini adalah mahasiswa PGSD STKIP Melawi. Terdapat 3 angkatan yaitu semester II, IV dan VI, dari 3 angkatan tersebut diambil 1 angkatan secara random dengan cara di undi yaitu semester VI A dan VI B diambil 25 orang per kelas yang dijadikan sampel subjek penelitian.

Dalam suatu penelitian untuk mendapatkan data yang relevan dengan masalah yang dihadapi diperlukan teknik pengumpulan data. Adapun teknik pengumpulan data yang digunakan dalam penelitian ini adalah teknik tes yang dilengkapi dengan wawancara.

Alat pengumpulan data yang digunakan dalam penelitian ini adalah soal tes. Soal tes terdiri dari 4 soal masingmasing terdiri dari 4 jenis bangun datar yaitu kubus, balok, prisma, limas dimana penyelesaiannya diikuti oleh subjek penelitian. Dengan kata lain, subjek bebas meyelesaikan soal menurut pemikiran mereka sendiri. Wawancara dilakukan terhadap tiga orang mahasiswa yang diambil secara acak dari masing-masing soal tes. Tiap mahasiswa diwawancarai pada soal-soal yang tidak dijawab dengan benar.

Teknik pengolahan data dalam penelitian ini adalah dengan menggunakan statistik deskriptif. Menurut Sugiyono (2009:147), statistik deskriptif adalah bagian statistik yang digunakan untuk menganalisis data dengan cara mendeskripsikan atau menggambarkan data yang telah terkumpul sebagaimana adanya tanpa bermaksud membuat kesimpulan yang berlaku untuk umum atau generalisasi. [8] Sesuai dengan tujuan penelitian yaitu untuk mengetahui analisis kemampuan berpikir kreatif matematis siswa pada materi bangun ruang di STKIP Melawi. Berdasarkan analisis kemampuan berpikir kreatif maka dilakukan perhitungan dengan persentase. 
Persentase $\%=\frac{\text { Jumlah skor yg di peroleh }}{\text { Skor maksimal }} \times 100 \%$

Kriteria:

$0 \%-50 \%$ dikategorikan rendah

$51 \%-80 \%$ dikategorikan sedang

$81 \%-100 \%$ dikategorikan tinggi

\section{HASIL DAN PEMBAHASAN}

\section{Hasil}

Hasil penelitian menunjukkan bahwa 48,5\% mahasiswa menjawab soal yang sesuai dengan indikator Fluency dan dikategorikan rendah, $45 \%$ mahasiswa menjawab soal yang sesuai dengan indikator Flexibility dan dikategorikan rendah, $44,5 \%$ mahasiswa menjawab soal yang sesuai dengan indikator Originality dan dikategorikan rendah, dan 46,5\% mahasiswa menjawab soal yang sesuai dengan indikator Elaboration dan dikategorikan rendah.

\section{Pembahasan}

Kemampuan berpikir kreatif matematis mahasiswa PGSD STKIP Melawi masih rendah dan perlu diberikan treatment yang dapat meningkatkan kemampuan berpikir kreatif matematis.Treatment yang diberikan harus sesuai dengan kemampuan berpikir kreatif sehingga mahasiswa akan menggunakan kemampuan berpikir kreatifnya saat menyelesaikan masalah khususnya pada materi bangun ruang.

\section{SIMPULAN}

Disimpulkan bahwa 48,5\% mahasiswa menjawab soal yang sesuai dengan indikator Fluency dan dikategorikan rendah, $45 \%$ mahasiswa menjawab soal yang sesuai dengan indikator Flexibility dan dikategorikan rendah, 44,5\% mahasiswa menjawab soal yang sesuai dengan indikator Originality dan dikategorikan rendah, dan 46,5\% mahasiswa menjawab soal yang sesuai dengan indikator Elaboration dan dikategorikan rendah.

\section{DAFTAR PUSTAKA}

Sari, N. P. 2015. Pengaruh permainan harta karun terhadap peningkatan kemampuan berpikir kreatif siswa Sekolah Dasar. Prosiding Seminar Nasional Matematika Dan Pendidikan Matematika. Yogyakarta: Universitas Negeri Yogyakarta.

Hendrayan, A. 2008. Pengembangan multimedia interaktif untuk meningkatkan kemampuan berpikir kritis dan kreatif siswa SMP dalam matematika. Tesis. Bandung: Sekolah Pascasarjana UPI Bandung.

Yulistiyarini, H. 2015. Mengembangkan kreativitas siswa melalui pembelajaran geomteri ruang. Seminar Nasional Pendidikan Matematika. Yogyakarta: Universitas Negeri Yogyakarta. 
Rosanti, U. 2015. Upaya meningkatkan kemampuan berpikir kreatif siswa kelas VII SMP pada pokok bahasan teorema pythagoras melalui pendekatan saintifik. Prosiding Seminar Nasional Matematika Dan Pendidikan Matematika. Yogyakarta: Universitas Negeri Yogyakarta.

Husen, I, Z. 2014. Meningkatkan kemampuan pemahaman dan berpikir kreatif serta disposisi matematik siswa SMP melalui pendekatan saintific. Prosiding Seminar Nasional Pendidikan Volume 2. Tasikmalaya: STKIP Siliwangi.

Sumarmo. 2010 Berfikir dan disposisi matematik: apa, mengapa, dan bagaimana dikembangkan para peserta didik. tidak diterbitkan. Bandung: FPMIPA UPI

Nasir, M. 1988. Metode Penelitian. Jakarta: ghalia indonesia

Sugiyono. 2009. Metode Penelitian Pendidikan (Pendekatan Kuantitatif, Kualitatif, dan $R \& D$. Bandung : CV. Alfabeta 